\title{
NEST SPACING AND ARCHITECTURE, AND SWARMING OF MALES OF Dinoponera quadriceps (HYMENOPTERA, FORMICIDAE) IN A REMNANT OF THE ATLANTIC FOREST IN NORTHEAST BRAZIL
}

\author{
VASCONCELLOS, A., SANTANA, G. G. and SOUZA, A. K. \\ Departamento de Sistemática e Ecologia, Centro de Ciências Exatas e da Natureza, Universidade Federal da \\ Paraíba, CEP 58051-900, João Pessoa, Paraíba, Brazil \\ Correspondence to: Alexandre Vasconcellos, Departamento de Sistemática e Ecologia, Centro de Ciências \\ Exatas e da Natureza, Universidade Federal da Paraíba, CEP 58051-900, João Pessoa, Paraíba, Brazil, \\ e-mail: avasconcellos@dse.ufpb.br \\ Received January 30, 2003 - Accepted March 20, 2003 - Distributed May 31, 2004
}

(With 3 figures)

\begin{abstract}
Dinoponera quadriceps is a queenless neotropical ponerinae ant. Nest spacing and abundance were investigated in a remnant of the Atlantic forest in Northeast Brazil. Males were captured with a light trap between August 1994 and July 1996. Nest density varied from 15 to $40 \mathrm{ha}^{-1}$. An overdispersion of nests suggests that the intraspecific competition may be an important factor regulating their spatial arrangement. Territory size was correlated with worker population size of the colonies. The nests had up to 16 chambers, with variations in their architecture closely related to habitat diversification. Populations varied from 12 to 97 adult workers per nest, with a mean density of 1,618 workers ha ${ }^{-1}$ and a live biomass of $461 \mathrm{~g} \mathrm{ha}^{-1}(\mathrm{n}=13$ nests). Males swarm continually throughout almost all months of the year, suggesting that production and swarming are more influenced by mechanisms that regulate the sexual activity of workers than by climatic factors.
\end{abstract}

Key words: Ponerinae, Dinoponera, population, competition, biomass, neotropical region.

\section{RESUMO}

Distribuição e arquitetura de ninhos e revoada de machos de Dinoponera quadriceps (Hymenoptera, Formicidae) em um remanescente de Mata Atlântica do Nordeste Brasileiro

Dinoponera quadriceps é uma formiga ponerine sem rainha da região Neotropical. A distribuição espacial e a abundância de seus ninhos foram investigadas em um remanescente de Mata Atlântica do Nordeste brasileiro. Machos foram capturados com armadilha luminosa de agosto de 1994 a julho de 1996. A densi-

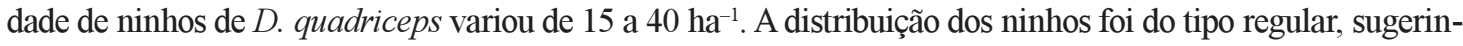
do que a competição intra-específica representa um importante fator na determinação de seu arranjo espacial. O tamanho do território foi correlacionado com a população de operárias da colônia. Os ninhos encontramse constituídos por até 16 câmaras, e sua arquitetura apresenta algumas variações de acordo com o habitat. A população variou de 12 a 97 operárias adultas por ninho, correspondendo a uma densidade média de 1.618 operárias ha ${ }^{-1} \mathrm{e}$ uma biomassa viva de $461 \mathrm{~g} \mathrm{ha}^{-1}(\mathrm{n}=13$ ninhos). Os machos foram capturados continuamente durante quase todos os meses do ano, sugerindo que a produção e a revoada são mais influenciadas pelos mecanismos que regulam a atividade sexual das operárias do que pelos elementos climáticos.

Palavras-chave: Ponerine, Dinoponera, população, competição, biomassa, região neotropical.

\section{INTRODUCTION}

The neotropical ant Dinoponera quadriceps is a typical queenless ponerinae, a species found almost only in the northeastern Brazilian caatingas (a xerophyllous vegetation), cerrados (a savannah-like vegetation), brejos de altitude (upland humid forest), and Atlantic forest (Kempf, 1971; Paiva \& Brandão, 1995). 
The organization and the dynamics of the reproductive system of $D$. quadriceps have been reported by several authors (Dantas-de-Araújo et al., 1990; Dantas-de-Araújo \& Jaisson, 1994; Monnin et al., 1998; Monnin \& Peeters, 1998, 1999; Monnin et al., 2002). However, field studies on foraging behaviour, competition, and eating habits are scarce, except for a brief report on predatory habits and foraging of this species (Dantas-de-Araújo, 1987).

Intra-and interspecific competition for nesting places and food resources is one of the main factors affecting the spatial distribution pattern of ant nest (Levings \& Franks, 1982; Levings, 1983; Ryti \& Case, 1984; Cushman et al., 1988). However, other factors like soil texture, vegetation density, microhabitat heterogeneity, ecological succession stage, edge effect, and anthropogenic disturbances, also act upon abundance and nest distribution in many ant habitats (Doncaster, 1981; Levings \& Traniello, 1981; Helle, 1985; Schoereder \& Coutinho, 1990; Johnson, 1992; Dugas, 2001; Soares \& Schoereder, 2001). Even nest architecture and population structure are influenced by habitat conditions (Hölldobler \& Wilson, 1990).

The aim of the present study is to evaluate the abundance and the spatial distribution pattern of nests and swarming frequency of males of $D$. quadriceps in a remnant of the Atlantic forest in northeast Brazil. Additional data to those reported by Dantas-deAraújo et al. (1990) and Paiva \& Brandão (1995) on architecture and population structure of nests of D. quadriceps are also here presented.

\section{MATERIAL AND METHODS}

The present study was carried out in a remnant of the Atlantic forest, ca. 5 ha, located on the campus of the Federal University of Paraíba, in João Pessoa, State of Paraíba, lat $6^{\circ} 7^{\prime} \mathrm{S}$ and long $34^{\circ} 45^{\prime} \mathrm{W}$. This remnant is one of the 11 fragments of Mata do Buraquinho, a typical segment of the Atlantic forest in João Pessoa (Andrade-Lima \& Rocha, 1971), a permanent protected area of the Brazilian Institute for the Environment and Natural Resources (IBAMA).

\section{Nest spacing}

The nest of $D$. quadriceps were mapped from observations carried out in an area of $100 \mathrm{~m} \times 100 \mathrm{~m}$. Nest openings were observed directly and by offering bait to ca. 200 workers. After localizing nest openings, the existence of nests was confirmed by monitoring the flux of workers. The search for nests by using bait was ended only when the linear tendency of the ratio baited workers : nests found stabilized for more than 40 baited workers. Young nests with less than 10 workers, and division of colonies during the mapping period are certainly the main sources of error in designing the spatial distribution of nests. The mapped area was subdivided in five quadrats of $100 \mathrm{~m} \times 20$ $\mathrm{m}$, in attempting to estimate the likely variation of $D$. quadriceps nest density per hectare.

The nest spacing pattern was estimated by calculating the $\mathrm{R}$ index (or the nearest neighbour index), according to Clark \& Evans (1954), also including a marginal zone around the surveyed area, according to Donnely (1978). The value of $\mathrm{R}=0$ indicates an aggregated distribution, $\mathrm{R}=1$ corresponds to a randomized distribution, and $\mathrm{R}=2.15$ represents a perfect and uniform distribution. The null hypothesis, predicting a randomized spatial distribution of nests, was obtained through the $\mathrm{z}$ test (Krebs, 1998).

\section{Ant population and nests architecture}

The population structure was investigated by opening 13 nests located in the quadrats selected for studying nest spacing. All nests were opened in August and September 2002. The population was formed by workers, males, pupae, larvae, and eggs.

The nest architecture was moulded in plaster plus water 1:2. The plaster mould was then wrapped with polythene and water-immersed in a graduated container for estimating the volume.

\section{Male swarming}

Light traps, with common fluorescent bulbs, were used for capturing males (Southwood, 1984). A 12 V battery supplied the trap device which was turned on by a photocell by 5 o'clock in the evening and turned off by 5:20 in the morning. The trap was hung from a tree at a height of $3 \mathrm{~m}$ from the forest floor. Collections were performed continually from August 1994 to July 1996, with intervals of three or four days, generating from seven to ten portions of biological material per month. Deterioration of the biological material made possible the collection of $D$. quadriceps males for nine days per month, sequentially or not.

\section{RESULTS}

Nests of $D$. quadriceps were not easily distinguished from the necromass on the soil surface, even considering the ones with slight surrounding mounds, ca. $4 \mathrm{~cm}$. The largest number of localizations (90\%) 
was obtained through offers of bait to foraging workers. The nest density varied from 15 to $40 \mathrm{ha}^{-1}$, with 29 nests recorded in the study area (Fig. 1). The aggregation index was $\mathrm{R}=1.534$, showing a regular distribution tendency. The $z$ value was 3.88 , higher than the tabulated $\mathrm{z}$ value $(3.09 ; \mathrm{p}<0.01)$; the null hypothesis of randomized nest spacing is consequently rejected. The population structure and some data on nest architecture are summarized in Table 1. The population mean of adult males was $\mathbf{5 5 . 8}$ individuals per nest $^{-1}$, which corresponds to a mean density of 1618 workers per ha- ${ }^{-1}$ and a live biomass of $461.2 \mathrm{~g} \mathrm{ha}^{-1}$. The size of the worker populations of the open nests was positively and significantly correlated to the distance from the nearest neighbour $\left(r_{s}=0.56 ; p<0.05\right)$.

Most D. quadriceps nests had a simple entrance, $3-9 \mathrm{~cm}$ wide and $2.5-4 \mathrm{~cm}$ high, and ca. $20 \%$ of the nests had two entrances. The largest number of chambers recorded per nest was 16 , the last of them at a $1.2 \mathrm{~m}$ depth. The total volume estimated from a nest with 12 chambers and a population of 72 workers was $11.7 \mathrm{~L}$. Most of the nests $(60 \%)$ were constructed at a minimum $3 \mathrm{~m}$ distance from a tree, and $40 \%$ of them were constructed under the branches and trunks of a fallen tree or at the base of trees 8$35 \mathrm{~m}$ in height. Quite variable distribution and architecture of chambers were observed, though most of them overlapped in the middle of the deepest part of the nest (Fig. 2). A positive and significant correlation was obtained between the population sizes and the number of nest chambers $\left(r_{s}=0.91 ; p<0.01\right)$.

Other co-habiting organisms were found in the nest chambers of $D$. quadriceps or in places adjacent to the chambers. The most common specimens were (i) Abapeba sp. (Araneae, Corinnidae) found close to the ant brood in $61 \%$ of the nests; (ii) termites (Isoptera, Termitidae) Embiratermes parvirostris, Anoplotermes sp., and Aparatermes sp., all found around the chambers, mainly under the refuse chamber; (iii) small molluscs Leptinaria sp. (Gastropoda, Subulinidae), very common on the soil necromass, many of them still alive in several chambers of the nest; and (iv) Pheidole spp. (Hymenoptera, Formicidae) living in small nests next to the chambers of $D$. quadriceps nests. Dicotyledon seeds were often found in the nests; some of them had already germinated.

The abundance of males captured in the light traps was low (Fig. 3). However, the relative frequency of collections throughout the period of 24 months of the present study ( $71 \%$ total) was high. Males were collected at least once in each of the 24 months, except in August of both years, when no capture was carried out. Three males was the maximum number of individuals collected in a single month (April and May 1996).

\section{DISCUSSION}

The spatial distribution of $D$. quadriceps nests showed to be typically regular, i.e., the most common pattern among ants (Levings \& Traniello, 1981). The maintenance of this kind of distribution in ants may require territorial behaviour by exclusion of workers or colonies or even by killing founder queens intruding into the foraging area of another previously established colony (Hölldobler \& Wilson, 1990). The D. quadriceps territory design may involve, besides other aspects, fidelity of workers to the foraging route, as was demonstrated for D. gigantea by Fourcassié et al. (1999). The same periodic visit to foraging areas by the workers helps indirectly to maintain the colony territory by preventing the establishment of new colonies or the invasion of such areas by other foragers (Gordon, 1992).

Our field observations showed that the meeting of $D$. quadriceps workers with neighbour conspecific workers involve mutual antennal contact while resident workers generally flee from intruders. However, an approximately 10 minute fight for a prey can happen between conspecific workers, which generally last until one of them gives up. Fierce fighting for a prey may cause serious consequences, like severed appendages of the workers as well as other damages.

The typically regular distribution of $D$. quadriceps nests suggests that intraspecific competition is a major determinant factor in spatial distribution of the nests. The fact that the most populated nests keep a longer distance from their neighbours than do the least populated nests supports this hypothesis, as already reported by Ryti \& Case $(1984,1986)$ after investigating Messor pergandei and Pogonomyrmex californicus. Inter-and intraspecific interactions are often pointed out as important in determining the structural assembly of ants (Levings \& Traniello, 1981; Levings \& Franks, 1982; Johnson et al., 1987; Hölldobler \& Wilson, 1990). Other wellknown factors, although reported elsewhere as having noticeable influence, like soil texture (Johnson, 1992), vegetation cover (Levings \& Traniello, 1981; Helle, 1985; Hammond, 1987), and heterogeneity of microhabitats (Soares \& Schoereder, 2001), are assumed by us to have only a secondary influence on distribution of the D. quadriceps colonies in the Atlantic forest which we studied. 
TABLE 1

Population size and structure of Dinoponera quadriceps nests in the Atlantic forest.

\begin{tabular}{|c|c|c|c|c|c|c|c|c|c|c|c|c|c|}
\hline \multirow{2}{*}{ Nest } & \multicolumn{2}{|c|}{ Adults } & \multicolumn{3}{|c|}{ Brood } & \multirow{2}{*}{ Openings } & \multirow{2}{*}{ Chambers } & \multirow{2}{*}{$\begin{array}{c}\text { Refuse } \\
\text { chambers }\end{array}$} & \multirow{2}{*}{$\begin{array}{c}\text { Depth } \\
(\mathrm{cm})\end{array}$} & \multirow{2}{*}{$\begin{array}{c}\text { Abapeba } \\
\text { sp. }\end{array}$} & \multirow{2}{*}{$\begin{array}{l}\text { Leptinaria } \\
\text { sp. }\end{array}$} & \multirow{2}{*}{$\begin{array}{c}\text { Pheidole } \\
\text { spp. }\end{array}$} & \multirow{2}{*}{ Termites } \\
\hline & Females & Males & Pupae & Larvae & Eggs & & & & & & & & \\
\hline 1 & 83 & 0 & 8 & 18 & 28 & 1 & 8 & 2 & 75 & + & + & & + \\
\hline 2 & 12 & 0 & 0 & 3 & 0 & 1 & 4 & 0 & 30 & + & & + & + \\
\hline 3 & 21 & 0 & 1 & 2 & 0 & 1 & 5 & 0 & 28 & & & & + \\
\hline 7 & 54 & 0 & 9 & 22 & 28 & 1 & 6 & 1 & 55 & + & & & + \\
\hline 8 & 43 & 0 & 19 & 15 & 22 & 1 & 6 & 1 & 60 & & + & + & + \\
\hline 9 & 55 & 0 & 9 & 15 & 0 & 1 & 11 & 4 & 69 & + & + & + & \\
\hline 11 & 32 & 0 & 6 & 10 & 12 & 2 & 5 & 2 & 43 & & & & + \\
\hline 12 & 82 & 3 & 16 & 23 & 42 & 1 & 9 & 3 & 120 & + & + & & + \\
\hline 13 & 97 & 4 & 34 & 29 & 29 & 2 & 16 & 5 & 105 & + & & + & + \\
\hline 17 & 42 & 3 & 32 & 37 & 47 & 1 & 6 & 1 & 55 & & + & & \\
\hline 20 & 42 & 0 & 12 & 20 & 29 & 1 & 7 & 3 & 55 & + & & & \\
\hline 22 & 74 & 0 & 14 & 24 & 38 & 2 & 13 & 6 & 72 & & + & + & \\
\hline 29 & 89 & 0 & 19 & 28 & 36 & 1 & 14 & 4 & 82 & + & & & \\
\hline Total & 726 & 10 & 179 & 246 & 311 & - & 110 & 32 & 844 & - & - & - & - \\
\hline Means & 55.8 & 0.7 & 13.7 & 18.9 & 23.9 & - & 8.4 & 2.46 & 64.9 & - & - & - & - \\
\hline
\end{tabular}

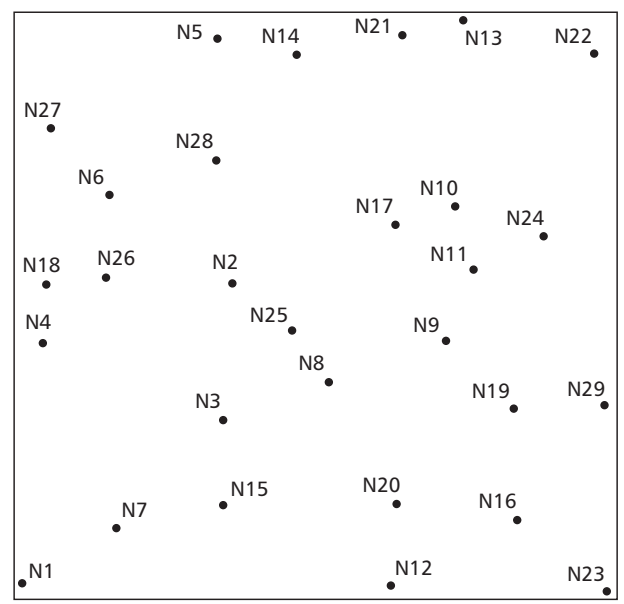

Fig. 1 - Nest spacing of Dinoponera quadriceps in one hectare of the Atlantic forest, northeast Brazil. Numbers at the side of the $N$ correspond to sequence of observed nests.

We estimated the density of $D$. quadriceps nests as 15-40 nests ha ${ }^{-1}$. Fowler (1985) reported an accentuated variation in density and spatial distribution of D. australis nests in Brazil and Paraguay in accordance with the different habitats. This author found in three different habitats a density of 3.4 and 11 nests $^{-1} \mathrm{a}^{-1}$, with a randomized distribution pattern and a regular pattern, respectively. Paiva \& Brandão (1995) reported 80 nests ha ${ }^{-1}$ randomly distributed in a cerrado vegetation. In both studies, nest dispersion was calculated by the index of Clark \& Evans (1954).

Dantas-de-Araújo et al. (1990) suggested that the predominance of adult workers over the number of eggs, larvae, and pupae in D. quadriceps nests are indicators of mature foundations, a fact that was noted in the present work, except for the nests numbered 2 and 3 . Nests with less than 10 workers were not found in our study, probably due to sampling error because of the low probability of workers being attracted by baits.

The architecture of D. quadriceps nests differs from those described by Dantas-de-Araújo et al. (1990) and Paiva \& Brandão (1995) in the following ways: (i) nests were not usually constructed at tree bases; (ii) we did not find any nest inside soil slopes; (iii) in more than $77 \%$ of the nests there was a single 
nest opening and none was found with more than two openings; and (iv) a nearly fixed height of chambers was noted in the study area, with no significant difference between superficial and deep chambers. Variations in nest architecture detected in the present work suggest some plasticity of $D$. quadriceps in response to each ecological specificity, e.g., nests constructed at tree bases in the caatinga and cerrado could be explained as an acclimatization to high temperatures in those ecosystems. Dantas-de-Araújo \& Jaisson (1994) state that in nests of $D$. quadriceps close to shrubs and trees roots, the temperature is sometimes $4^{\circ} \mathrm{C}$ lower than in the ambient. In the Atlantic forest, tree canopies and the necromass layer on the soil provide a mild microclimate, enabling ants to construct their nests far from tree trunks. Hölldobler \& Wilson (1990) state that the habitat also affects the social behaviour of ants which relates to alarm signals, recruitment, and shifts in the foraging pattern of the colony.

Swarming of $D$. quadriceps males occurred in 17 out of 24 months of collection, apparently demonstrating that the colonies have a continual pro- duction process. However, the presence of males in open nests shows an asynchronism among the colonies. Climatic factors, like rainfall, temperature, and relative humidity seem to exert a weak or nil influence on production and swarming of males in the forest remnant we studied. Delabie et al. (2000) also observed that the swarming of males of Thaumatomyrmex atrox and T. contumax occurs on a continual, casual, and not-seasonally-regulated basis.

According to Monnin \& Peeters (1998) the sexual receptivity of $D$. quadriceps workers is unpredictable since it is directly related to death of the gamergate (the fertilized worker of the colony). In an orphaned colony, the virgin alpha worker leaves the nest for a few minutes to copulate, and after successfully, doing so she returns to the nest with a new gamergate status. Considering that the death of a gamergate is a fortuitous event, production and swarming of $D$. quadriceps males by all colonies of an ecosystem seem to represent an adaptation of the species which enables males to be present in the colony, when a virgin alpha worker of an orphaned colony leaves the nest to copulate.

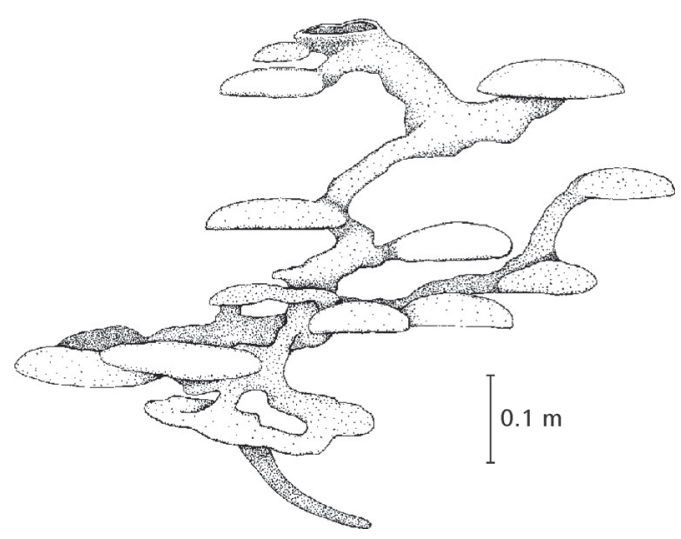

Fig. 2 - The architecture of a Dinoponera quadriceps nest in the Atlantic forest, with a population size of 74 adult workers.

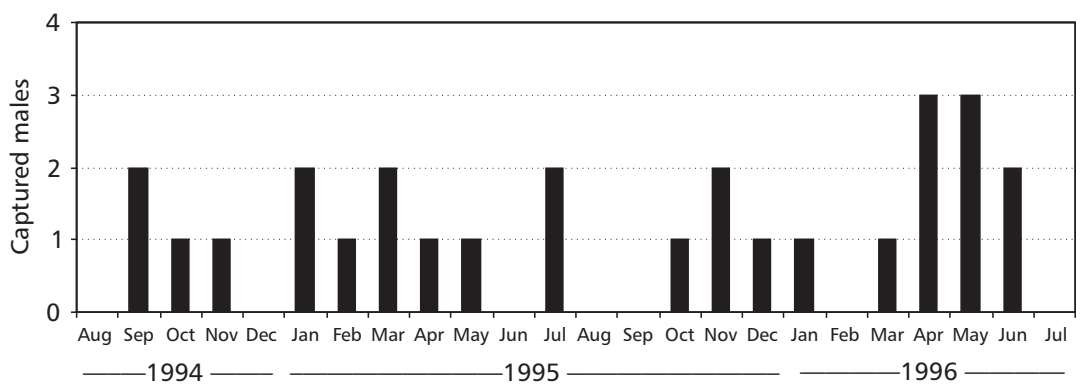

Fig. 3 - Capture of Dinoponera quadriceps males throughout 24 months in the Atlantic forest. 
Acknowledgments - We thank Dr. Jacques H.C. Delabie and Dr. Adelmar G. Bandeira for helpful comments and suggestions on the manuscript, Dr. Carlos R. F. Brandão for identifying the Dinoponera species; drs. Luiz Ricardo L. Simone and Alexandre B. Bonaldo for identifying molluses and spiders, respectively; Lemuel O. Leite and Rodrigo O. Pessoa for helping us in the hard digging tasks; Dr. Lucilene G. S. Medeiros for capturing D. quadriceps males with her ingenious light trap; and also to CAPES for PhD. and MSc. grants to A. Vasconcellos and A. K. Souza, respectively.

\section{REFERENCES}

ANDRADE-LIMA, D. \& ROCHA, N. G., 1971, Observações preliminares sobre a Mata do Buraquinho, João Pessoa. $P b$. An. Ins. Ciências Biológicas, 1: 47-61.

CLARK, P. J. \& EVANS, F. C., 1954, Distance to nearest neighbor as a measure of spatial relationships in populations. Ecology, 35: 445-453.

CUSHMAN, J. H., MARTINSEN, G. D. \& MASEROLL, A. L., 1988, Density- and size-dependent spacing of ant nests evidence for intraspecific competition. Oecologia, 77: 522-525.

DANTAS-DE-ARAÚJO, C. Z., 1987, Résultats préliminaires sur la biologie et al'éthologie de Dinoponera quadriceps (Hymenoptera: Formicidae). Mémoire de DEA, Université Paris XIII, 31p.

DANTAS-DE-ARAÚJO, C. Z., LACHAUD, J. P. \& FRESNEAU, D., 1990, Le système reproductif chez une ponérine sans reine: Dinoponera quadriceps Santschi. Behav. Proc., 22: 101-111.

DANTAS-DE-ARAÚJO, C. Z. \& JAISSON, P., 1994, Modes de fondation des colonies chez la fourmi sans reine Dinoponera quadriceps Santschi (Hymenoptera, Formicidae, Ponerinae). Actes Coll. Insects Soc., 9: 79-88.

DELABIE, J. H. C., FRESNEAU, D. \& PEZON, A., 2000, Notes on the ecology of Thaumatomyrmex spp. (Hymenoptera: Formicidae: Ponerinae) in Southeast Bahia, Brazil. Sociobiol., 36(3): 571-584.

DONCASTER, C. P., 1981, The spatial distribution of ants' nests on Ramsey Island, South Wales. J. Anim Ecol., 50: 195-218.

DONNELY, K., 1978, Simulations to determine the variance and edge-effect of total nearest neighbor distance. In: I. Hodder (ed.), Simulation methods in archaeology. Cambridge University Press, London, pp. 91-95.

DUGAS, D. P., 2001, The influence of arroyo edges on Pogonomyrmex rugosus nest distribution in the Chihuahuan Desert, New Mexico. J. Arid. Environ., 47: 153-159.

FOURCASSIÉ, V., HENRIQUES, A. \& FONTELLA, C., 1999, Route fidelity and spatial orientation in the ant Dinoponera gigantea (Hymenoptera, Formicidae) in a primary forest: a preliminary study. Sociobiol., 34(3): 505-524.

FOWLER, H. G., 1985, Populations, foraging and territoriality in Dinoponera australis (Hymenoptera, Formicidae). Revta. bras. Ent., 29(3/4): 443-447.

GORDON, D. M., 1992, How colony growth affects forager intrusion in neighboring harvester ant colonies. Behav. Ecol. Sociobiol., 31: 417-427.

HAMMOND, B., 1987, An example of edge effects on ants in the western Australian wheatbelt. The West. Austr. Nat., 16: 184-185.
HELLE, P., 1985, Invertebrate numbers in edges between clearing-fellings and mature forests in northern Finland. Sil. Fen., 19: 281-294.

HÖLLDOBLER, B. \& WILSON, E. O., 1990, The ants. Belknap Press, Cambridge, 732p.

JOHNSON, R. A., 1992, Soil texture as an influence on the distribution of the desert seed-havester ants Pogonomyrmex rugosus and Messor pergandei. Oecologia, 89: 118-124.

JOHNSON, L. K., HIBBELE, S. P. \& FREENER, D. H., 1987, Defense of food supply by eusocial colonies. Am. Zool., 27: 347-358.

KEMPF, W. W., 1971, A preliminar review of the ponerine ant genus Dinoponera Roger (Hymenoptera: Formicidae). Studia Ent., 14(1-4): 369-394.

KREBS, C. J., 1998, Ecological methodology. Addison Wesley Longman, Menlo Park, California, 620p.

LEVINGS, S. C. \& TRANIELLO, J. F. A., 1981, Territoriality, nest dispersion, and community structure in ants. Psyche, 88: 265-319.

LEVINGS, S. C. \& FRANKS, N. R., 1982, Patterns of nest dispersion in a tropical ground ant community. Ecology, 63: 338-344.

LEVINGS, S. C., 1983, Seasonal, annual, and among-site variation in the ground ant community of a deciduous tropical forest: some causes of patchy species distributions. Ecol. Monogr., 53: 435-455.

MONNIN, T., MALOSSE, C. \& PEETERS, C., 1998, Solidphase microextraction and cuticular hydrocarbon differences related to reproductive activity in queenless ants. J. Chem. Ecol., 24(3): 473-490.

MONNIN, T. \& PEETERS, C., 1998, Monogyny and regulation of worker mating in the queenless ant Dinoponera quadriceps. Anim. Behav., 55: 299-306.

MONNIN, T. \& PEETERS, C., 1999, Dominance hierarchy and reproductive conflicts among subordinates in a monogynous queenless ant. Behav. Ecol., 10(3): 323-332.

MONNIN, T., RATNIEKS, F. L. W., GRAEME, R. J. \& BEARD, R., 2002, Pretender punishment induced by chemical signalling in a queenless ant. Nature, 419: 61-65.

PAIVA, R. V. S. \& BRANDÃO, C. R. F., 1995, Nests, worker population, and reproductive status of workers, in the giant queenless ponerine ant Dinoponera roger (Hymenoptera Formicidae). Ethol. Ecol. Evol., 7: 297-312.

RYTI, R. T. \& CASE, T. J., 1984, Spatial arrangement and diet overlap between colonies of desert ants. Oecologia, 62: 401404.

RYTI, R. T. \& CASE, T. J., 1986, Overdispersion of ant colonies: a test of hypotheses. Oecologia, 69(3): 446-453.

SCHOEREDER, J. H. \& COUTINHO, L. M., 1990, Fauna e estudo zoossociológico das espécies de saúvas (Formicidae, Attini) de duas regiões de Cerrado do estado de São Paulo. Revta. Bras. Ent., 34(3): 561-568.

SOARES, S. M. \& SCHOEREDER, J. H., 2001, Ant-nest distribution in remnant of tropical rainforest in southeastern Brazil. Insectes Soc., 48: 280-286.

SOUTHWOOD, T. R. E., 1984, Ecological methods, with particular reference to the study of insect populations. Chapman and Hall, London, 524p. 